\title{
Fine-tuned characterization of Staphylococcus aureus Newbould 305, a strain associated with mild and chronic mastitis in bovines
}

Vincent Peton ${ }^{1,2 \dagger}$, Damien S Bouchard ${ }^{1,2+}$, Sintia Almeida ${ }^{3}$, Lucie Rault ${ }^{1,2}$, Hélène Falentin ${ }^{1,2}$, Julien Jardin ${ }^{1,2}$, Gwénaël Jan ${ }^{1,2}$, David Hernandez ${ }^{4}$, Patrice François ${ }^{4}$, Jacques Schrenzel ${ }^{4}$, Vasco Azevedo ${ }^{3}$, Anderson Miyoshi ${ }^{3}$, Nadia Berkova ${ }^{1,2}$, Sergine Even ${ }^{1,2}$ and Yves Le Loir ${ }^{1,2^{*}}$

\begin{abstract}
S. aureus is a major aetiological agent of ruminant mastitis worldwide. The chronic nature of S. aureus mastitis makes it difficult to cure and prone to resurgence. In order to identify the bacterial factors involved in this chronicity, Newbould 305 (N305), a strain that can reproducibly induce mild and chronic mastitis in an experimental setting, was characterized in depth. We employed genomic and proteomic techniques combined with phenotype characterization, in order to comprehensively analyse N305. The results were compared with data obtained on S. aureus RF122, a strain representative of the major clone involved in severe bovine mastitis worldwide. Five mobile genetic elements were identified in the N305 genome as carrying virulence factors which correlated with phenotypic features such as cytotoxicity, mammary epithelial cell invasion or host-adaptation. In particular, the presence and characteristics of surface exposed proteins correlated well with the greater adhesion and internalization capacities of N305 in bovine mammary epithelial cells. N305 also displayed less diversity of toxin genes but secreted larger quantities of these toxins, associated with a higher cytotoxicity potential. Our data are consistent with the invasiveness and host-adaptation features which contribute to the chronicity of $S$. aureus mastitis. Mobile genetic elements, exoproteins and surface exposed proteins constitute good targets for further research to explore the underlying mechanisms related to mastitis chronicity.
\end{abstract}

\section{Introduction}

Mastitis is an inflammation of the mammary gland, which commonly results from a bacterial infection. This infection first induces local benign symptoms and can rapidly evolve towards general and severe symptoms and result in systemic infection. Mastitis dramatically impacts animal health and milk quality, and causes considerable economic losses throughout the global milk production chain [1]. Staphylococcus aureus is a major aetiological agent of ruminant mastitis, which is often difficult to cure and is prone to resurgence and chronicity [2]. There is therefore a need to better understand the mechanisms underlying the chronicity phenomenon

\footnotetext{
* Correspondence: yves.leloir@rennes.inra.fr

${ }^{+}$Equal contributors

'INRA, UMR 1253 STLO, 65 rue de Saint Brieuc, 35042 Rennes Cedex, France ${ }^{2}$ Agrocampus Ouest, UMR1253 STLO, 85 rue de Saint Brieuc, 35042 Rennes Cedex, France

Full list of author information is available at the end of the article
}

in order to efficiently tackle and prevent $S$. aureus mastitis. Unlike Escherichia coli mastitis, the severity of which is mainly determined by host factors and not strain features, the severity of $S$. aureus mastitis mostly derives from inter-strain variations in terms of virulence potential $[3,4]$. Indeed, some $S$. aureus strains have reportedly induced chronic mastitis associated with mild symptoms, while others can cause severe mastitis.

Several hypotheses have been put forward to explain the chronicity of $S$. aureus mastitis, amongst which cytotoxicity, biofilm formation and tissue invasion have been the most widely investigated. S. aureus strains that secrete high levels of Panton-Valentine leukocidin and alpha toxin are associated with severe but not persistent mastitis [5-7]. By contrast, low-level cytotoxicity may facilitate persistence of the infection. Biofilm formation may also help $S$. aureus to resist antibiotic therapy and host defenses. The genetic loci bap and ica, which are 
involved in biofilm formation, are indeed associated with strains that cause less severe but more persistent mastitis [8]. Finally, the ability to invade and survive within mammary epithelial cells may also enable S. aureus to evade the host immune response and the curative treatments. All the evasive tactics that have been developed by $S$. aureus probably influence the rate of cures achieved by antibiotic therapies, and thus make $S$. aureus mastitis an infection difficult to treat.

In contrast with the huge efforts dedicated to the development of preventive and treatment strategies against $S$. aureus mastitis, little is still known about the genomics of $S$. aureus ruminant isolates. Compared to the hundreds of fully sequenced human isolates, only one bovine strain (RF122) and one ovine strain (ED133) have been fully sequenced, the former in 2007 [9] and the latter in 2010 [10]. We recently completed the set of publicly available genomic data on ruminant isolates through the sequencing and characterization of two ovine strains [3,11] and the recent release of three bovine S. aureus S1 [12], M186 [13], Newbould 305 (N305) genomes [14].

N305, a strain isolated in 1958 from a clinical case of cow mastitis in Orangeville, Ontario, Canada [15] has been used as a model strain of $S$. aureus mastitis isolates during numerous studies relative to vaccine development $[16,17]$, antibiotic treatments [18], in vitro characterization [19] or in vivo experiments on bovine [20] and mouse models [21]. In particular, N305 was shown to reproducibly induce mild and chronic mastitis in the context of experimental infections [22,23]. But despite its widespread use as a prototype strain for chronic infections during academic and industrial research projects, N305 remains poorly characterized. A clearer understanding of how a strain is able to induce chronic mastitis is crucial to finding the Achilles heel in the pathogenicity of S. aureus and then developing more effective control strategies. In a previous work, we showed that S. aureus N305 and RF122 displayed different capacities for adhesion and internalization in bovine mammary epithelial cells [24]. To gain further insight into the characteristics of $S$. aureus that correlate with the hypotheses evoked to explain the chronicity of mastitis, we have now characterized N305 in depth at the genome, proteome and phenotype levels, and compared our findings with those obtained on S. aureus RF122. The results revealed that several features of N305 may contribute to the development of chronic mastitis, including mobile genetic elements (MGEs) and the types and production levels of toxins and surface proteins.

\section{Materials and methods}

\section{Bacterial strains, growth conditions}

Staphylococcus aureus Newbould 305 (hereinafter referred to as N305) [15] and RF122 [9] were isolated from cases of bovine mastitis. These strains are well characterized and can reproducibly induce severe mastitis (RF122; [25]; JR. Fitzgerald, University of Edinburgh, personal communication) or mild mastitis (N305) under experimental conditions $[9,15]$. N305 was kindly provided by Dr F. Gilbert (INRA Tours) and received as a lyophilized vial provided by D.S. Postle (College of Veterinary Medicine, Cornell University, Ithaca, New York) in 1975 and prepared from the original Newbould 305 isolate supplied by F.H.S. Newbould. One can therefore consider it is close to the original isolate (F. Gilbert and P. Rainard, INRA Tours, personal communication). Subcultures prior to invasion assays were performed overnight as follows. S. aureus strains were grown in brain heart infusion medium (BHI; Becton Dickinson, Le Pont de Claix, France) at $37{ }^{\circ} \mathrm{C}$ under agitation $(180 \mathrm{rpm})$. The cultures were washed once with phosphate-buffered saline (PBS) and suspended at different concentrations in Dulbecco's modified Eagle's medium (DMEM; pH 7.4; D. Dutscher, Brumath, France). Bacterial concentrations in subcultures were estimated by spectrophotometric measurements at $600 \mathrm{~nm}\left(\mathrm{OD}_{600}\right)$. They were further confirmed using a micromethod, as previously described [26]. The resulting $S$. aureus populations (in $\mathrm{CFU} / \mathrm{mL}$ ) were determined on mannitol salt agar (MSA; D. Dutscher, Brumath, France) after $24 \mathrm{~h}$ of incubation at $37^{\circ} \mathrm{C}$.

\section{Genome comparison of RF122 and N305}

The N305 strain was fully sequenced using the Illumina technique. The whole genome sequencing and assembly strategies are described in Bouchard et al. [14]. The N305 genome sequence was analysed using SurfG + to predict protein locations (potentially surface exposed (PSE), secreted, membrane and cytoplasmic proteins) [27], and PIPS, a software suite designed for the prediction of pathogenicity islands which, in an integrative manner, utilizes multiple features (such as atypical $\mathrm{G}+\mathrm{C}$ content, codon usage deviation, virulence factors, hypothetical proteins, transposases, flanking tRNA and the absence of this structure in non-pathogenic organisms) to detect pathogenicity islands [28]. For the PIPS analysis, the genome sequences of the strains Staphylococcus xylosus C2a (kindly provided by R. Talon and S. Leroy, INRA Clermont-Ferrand) and Staphylococcus carnosus TM300 [29] were used as references. The assignment of protein function to the coding sequences (CDSs) of the two genomes (N305 and RF122) was performed manually using the results from BLASTP and the COG (Clusters of Orthologous Groups) [30].

These genome sequences are available at DDBJ/EMBL/ GenBank under the accession numbers AKYW00000000 (N305) and NC_007622 (RF122). 


\section{Phenotype characterization Biofilm formation}

The two $S$. aureus strains were assayed for biofilm formation using crystal violet staining. The bacteria were subcultured twice in $\mathrm{BHI}$ before adjusting the $\mathrm{OD}_{600 \mathrm{~nm}}$ to 0.004 (corresponding approximately to $10^{6} \mathrm{CFU} / \mathrm{mL}$ ) in BHI containing $4 \mathrm{~g} / \mathrm{L}$ glucose (hereinafter named BHIglu), in order to promote biofilm formation. Growth was performed in 96-well microtiter plates with $200 \mu \mathrm{L}$ of bacterial suspension per well. BHIglu alone was used as a negative control. The biofilm staining assays were performed following an incubation period of $24 \mathrm{~h}$ at $37{ }^{\circ} \mathrm{C}$. The microtiter plates were washed twice with phosphatebuffered saline (PBS), fixed for $20 \mathrm{~min}$ at $80{ }^{\circ} \mathrm{C}$ and stained for $10 \mathrm{~min}$ with $1 \%(\mathrm{w} / \mathrm{v})$ crystal violet solution, freshly diluted 10-fold in distilled water. The plates were then washed twice with distilled water and allowed to dry at room temperature. The crystal violet was dissolved in $200 \mu \mathrm{L}$ of acetic acid solution (33\% in distilled water) for 10 min under gentle agitation. Optical density was measured at $595 \mathrm{~nm}$ using a Spectramax spectrometer. The $S$. aureus strain MW2 was used as an internal normalization standard and biofilm formation by N305 and RF122 was expressed as a ratio $\mathrm{OD}_{\mathrm{N} 305} / \mathrm{OD}_{\mathrm{MW} 2}$, and $\mathrm{OD}_{\mathrm{RF} 122} / \mathrm{OD}_{\mathrm{MW} 2}$.

\section{Cytotoxicity}

To assess their cytotoxic effect, the viability of MAC-T cells was measured during their incubation with a culture supernatant at $24 \mathrm{~h}$ post-infection using methylthiazolyldiphenyltetrazolium bromide (MTT), as previously described [31]. Briefly, the strains were pre-cultured in RPMI 1640 (Sigma, Saint Quentin Fallavier, France) supplemented with 2.2 'dipyridyl (200 mM, Sigma) and then diluted 1000-fold in fresh RPMI + deferoxamine mesylate (152 mM, Sigma). These iron-depleted conditions were previously shown to mimic the mastitis context and to increase the expression of virulence factors [32]. S. aureus strains were grown without agitation at $37{ }^{\circ} \mathrm{C}$ under microaerophilic conditions, in $50 \mathrm{~mL}$ tubes. After $24 \mathrm{~h}$ of growth, the cultures were centrifuged and the supernatants were filtered on $0.22 \mu \mathrm{m}$ units before being diluted in fresh DMEM at a ratio of $1: 1$. The cells were incubated for $24 \mathrm{~h}$ in this medium and then $0.5 \mathrm{mg} / \mathrm{mL}$ MTT were added for $4 \mathrm{~h}$ at $37{ }^{\circ} \mathrm{C}$ in $5 \% \mathrm{CO}_{2}$. The medium was removed and isopropanol was added for $30 \mathrm{~min}$ under shaking at $350 \mathrm{rpm}$. Absorbance was read at $570 \mathrm{~nm}$ with a background at $690 \mathrm{~nm}$. Cells treated with PBS diluted in DMEM (ratio $1: 1)$ were used as a negative control (100\% viability). Relative viability was expressed versus PBS-treated cells.

\section{Proteolysis}

Proteolysis capacity of $S$. aureus strains was assessed using a simple plate assay to visualize milk protein degradation.
Briefly, culture supernatants were prepared as described in cytotoxicity assays, filtered on $0.22 \mu \mathrm{m}$ units, and concentrated 10x in a Speed Vac Concentrator (Savant, Thermo Scientific). Fifty $\mu \mathrm{L}$ of these supernatants were deposited in wells in PCA agar medium supplemented with $5 \%$ of skimmed milk. A translucent halo around the wells indicates the casein lysis.

\section{Plasma coagulation}

To confirm the presence in N305 of a bovine variant of von Willebrand binding protein, plasma samples from cows and goats were prepared from blood collected in EDTA-coated tubes (blood samples kindly provided by Jacques Lassalas, UMR1348 PEGASE, INRA Agrocampus Ouest, Rennes, France). Rabbit plasma (Sigma) was used as a positive control for coagulase activity. A volume corresponding to $10^{8} \mathrm{CFU}$ of N305 or RF122 (overnight culture on BHI) was pelleted, washed once in PBS and re-suspended in $300 \mu \mathrm{L}$ serum. Coagulation was checked after $4 \mathrm{~h}$ of incubation at $37^{\circ} \mathrm{C}$ by inverting the tubes.

\section{2-Dimensional gel electrophoresis for the total proteome and secretome of RF122 and N305}

For 2D-PAGE, protein samples were prepared as described previously, with some minor changes [3]. Briefly, $S$. aureus strains were pre-cultured in RPMI 1640 supplemented with $2.2^{\prime}$-dipyridyl $(200 \mu \mathrm{M})$ to chelate extracellular iron and consequently reduce intracellular iron stocks. The cultures were then diluted 1:1000 in fresh RPMI 1640 with deferoxamine $(152 \mu \mathrm{M})$. S. aureus strains were grown without agitation at $37{ }^{\circ} \mathrm{C}$ under microaerophilic conditions, in $500 \mathrm{~mL}$ flasks for the supernatant fraction or in $50 \mathrm{~mL}$ tubes for the total fraction and shaving experiments. These conditions were previously shown to best mimic growth in vivo during mastitis [32]. The cultures were centrifuged at $7000 \mathrm{~g}$ for $10 \mathrm{~min}$ and the supernatants were filtered through a $0.22 \mu \mathrm{m}$ filter unit. Total cell lysate proteins were obtained from bacterial pellets, as previously described [32].The supernatant proteins were precipitated with $10 \%$ TCA at $4{ }^{\circ} \mathrm{C}$ overnight. The samples were centrifuged at $9000 \mathrm{~g}$ for $1 \mathrm{~h}$ at $4{ }^{\circ} \mathrm{C}$. Protein pellets were washed three times with 96\% ethanol and then dried. Proteins were solubilized in urea $8 \mathrm{M}$. The protein concentration was determined using a Bradford test (Sigma). A constant amount of proteins was used for each acrylamide gel so as to enable determination of a relative abundance of a given protein with respect to the total of secreted proteins. Three biological replicates were used for each analysis.

To purify the protein extracts, a 2D Clean Up kit (GE Healthcare, Orsay, France) was used according to the manufacturer's instructions, and then the samples were treated as described previously [3]. Images of the gels 
were analysed using SameSpot software (TotalLab Ltd., Proteomics consult, Belgium), as previously described $[1,32,33]$. Spot volumes were determined and normalized with regard to the total volume of the gel. After this normalization, spots with a minimal fold change of 2 and an ANOVA e-value lower than 0.005 were selected for mass spectrometry analysis. The gel pieces were processed exactly as described previously [3,34]. A shaving technique was used to analyse the PSE proteins. S. aureus cultures were centrifuged at $7000 \mathrm{~g}$ for $10 \mathrm{~min}$ and the total cell and supernatant fractions were treated separately. The pellets were washed twice with PBS. The bacteria were re-suspended in PBS with sufficient $5 \mathrm{mM}$ DTT to reach 20 units of $\mathrm{OD}_{600 \mathrm{~nm}}$. Five hundred $\mu \mathrm{L}$ of this suspension were incubated with $20 \mu \mathrm{g}$ trypsin for $1 \mathrm{~h}$ at $37^{\circ} \mathrm{C}$ under agitation $(180 \mathrm{rpm})$ and then centrifuged at $10000 \mathrm{~g}$. The supernatants were filtered through a $0.22 \mu \mathrm{m}$ filter and incubated overnight with $1 \mu \mathrm{g}$ trypsin at $37^{\circ} \mathrm{C}$ under agitation. Trypsin digestion was stopped by adding $15 \mu \mathrm{L} 5 \%$ TFA. The controls did not display any significant loss of viability from the counts of CFUs before and after shaving.

\section{Identification of proteins}

Proteins were identified using NanoLC-ESI-MS/MS as described by Le Maréchal et al. [1] with some minor modifications. Peptides were identified using the X! Tandem software. The database used for protein identification was composed of predicted proteins based on the RF122 and N305 genome sequences [9,14], together with protein data on Staphylococcus aureus (taxon 1280) in the UniProtKB database [35], in order to obtain a statistically significant identification. To achieve valid identification with a high degree of confidence, each protein must have a minimum of two peptides corresponding to a $p$-value lower than 0.05 . An auto-validation of peptides from the X!Tandem search results was performed using X!TandemPipeline [36]. Prediction of the sub-cellular localization of proteins was achieved using PSORTb 3.0.2 software [37]. Validated and identified proteins were then sorted by Clusters of Orthologous Groups (COGs) using EggNOG 3.0 software [38].

Regarding proteins identified by trypsin shaving, only those identified with at least two peptides in one strain and less than two peptides in the other strain were considered as more abundant in the first strain.

\section{Statistical analysis}

All experiments were carried out in triplicates (biological repeats). The differences in biofilm formation and cytotoxicity assays were assessed using paired Student's $t$ tests considering a $P$ value lower than 0.05 . In proteome analyses, proteins were considered as over expressed in total proteome or exoproteome when ANOVA e-value given by SameSpot software was lower than 0.005 and the minimal fold change was 2 .

\section{Results}

Comparison of the gene contents of S. aureus RF122 and Newbould 305

The general features of the N305 genome are summarized in Table 1, which also includes the general features of RF122 [9]. Predicted proteins were functionally categorized using the COGs database. The COGs distributions were similar in the two genomes (see Additional file 1$)$. The majority of the genes $(n=2518)$ were common to both strains. The core genome covers up to $91.5 \%$ and $94.5 \%$ of the CDSs of N305 and RF122, respectively. However, a comparison of the sequences of N305 and RF122 revealed some differences in their overall genome content. A total of 48371 single nucleotide polymorphisms (SNPs) were found in N305 when compared to RF122. Among the SNPs located in the CDSs, 10470 were nonsynonymous and 1690 corresponded to insertions or deletions. In order to better understand the genomic features responsible for the phenotypic differences between N305 and RF122, we further analysed the gene content of $S$. aureus N305 in terms of putative MGE, which appeared to be the principal source of variability between the two genomes.

Analysis of the N305 genome using the PIPS pipeline [28] predicted the presence of five putative $S$. aureus Pathogenicity Islands (SaPIs). SaPI-N305_1 (contig 1) contained 35 predicted CDSs markedly similar to the CDSs of $\nu \mathrm{Sa} \beta$ already described in RF122 and S. aureus MW2 (Figure 1A). SaPI-N305_2 (contig 1) contained 15 CDSs markedly similar to a SaPIbov found in strain D30 (isolated in the context of human nasal carriage) [39] (Figure 1B). SaPI-N305_3 and SaPI-N305_4 were two adjacent putative SaPIs (contig 2) containing 19 and 28 CDSs, respectively. SaPI-N305_3 shared marked similarity

Table 1 General features of Newbould 305 and comparison to RF122 genome

\begin{tabular}{lll}
\hline & Newbould 305 & RF122 \\
\hline Size (bp) & 2791699 & 2742531 \\
GC \% & 32.8 & 32.8 \\
Number of CDSs & 2752 & 2664 \\
Number of SNPs & 48371 & \\
CORE N305 x RF122 & 2518 (e-value $=1^{\mathrm{e}-5} /$ identity $\left.>70 \%\right)$ \\
Pseudogenes & 6 & 76 \\
Protein coding genes with COGs & $2052(70.53 \%)$ & $1903(70.74 \%)$ \\
rRNA genes & $5 S$ rRNA $=7$ & $5 S$ rRNA $=6$ \\
& 165 rRNA $=6$ & 165 rRNA $=5$ \\
& 235 rRNA $=7$ & $23 S$ rRNA $=5$ \\
tRNA genes & 56 & 64 \\
\hline
\end{tabular}


with SaPIbov4 and SaPIbov5, which both carry a bovine variant of von Willebrand factor binding protein $\left(\nu w b^{S b o 5}\right)$ (Figure 1C). SaPI-N305_4 shared similarity with SaPIn2, which was first described in the human $S$. aureus strain, N315 [40] (Figure 1D). SaPI-N305_5 (contig 6) contained 35 CDSs, 17 of which were found to be very similar to SaPI2. PIPS analysis also revealed the presence of two putative bacteriophages, on contig 5, containing 34 CDSs and 19 CDSs with homology to Bacteriophage 80alpha and bacteriophage 187 , respectively.

We further analysed the N305 genome while focusing on genes suspected of being implicated in the chronicity of infections, i.e. genes reportedly involved in biofilm formation, cytotoxicity and invasiveness (Table 2). This revealed differences between the RF122 and N305 strains. Some genes were only found in N305, encoding proteins such as the delta-hemolysin (Hld), the bovine variant of the von Willebrand binding protein $\left(\mathrm{vWb}^{\mathrm{Sbo5}}\right)$, fibronectin binding protein B (FnbB), S. aureus surface protein G (SasG) and 1-acyl-sn-glycerol-3-phosphate acyltransferase $(\mathrm{PlsC})$. These factors are involved in the colonization of host tissue ( $\mathrm{vWb}^{\mathrm{Sbo} 5}$, FnbB, SasG, and $\mathrm{PlsC}$ ) or cytotoxic effects (Hld). A cluster of set genes (staphylococcal enterotoxins) was also found in SaPIN305_4 (Figure 1D and Table 2). None of the strains possess the bap gene, which encodes a protein implicated in biofilm synthesis in S. aureus. However, they both have the $i c a A D B C$ operon and the icaR regulator. In terms of virulence regulation, the accessory gene regulator (agr system) of N305 is of type I (while RF122 is $\operatorname{agrII}$ ), as shown by the genome sequence analysis.

Some genes were only found in RF122, encoding for leukocidin M (LukM) and Panton-Valentin leukocidin F (LukF'-PV), toxic shock syndrome toxin 1 (TSST-1),

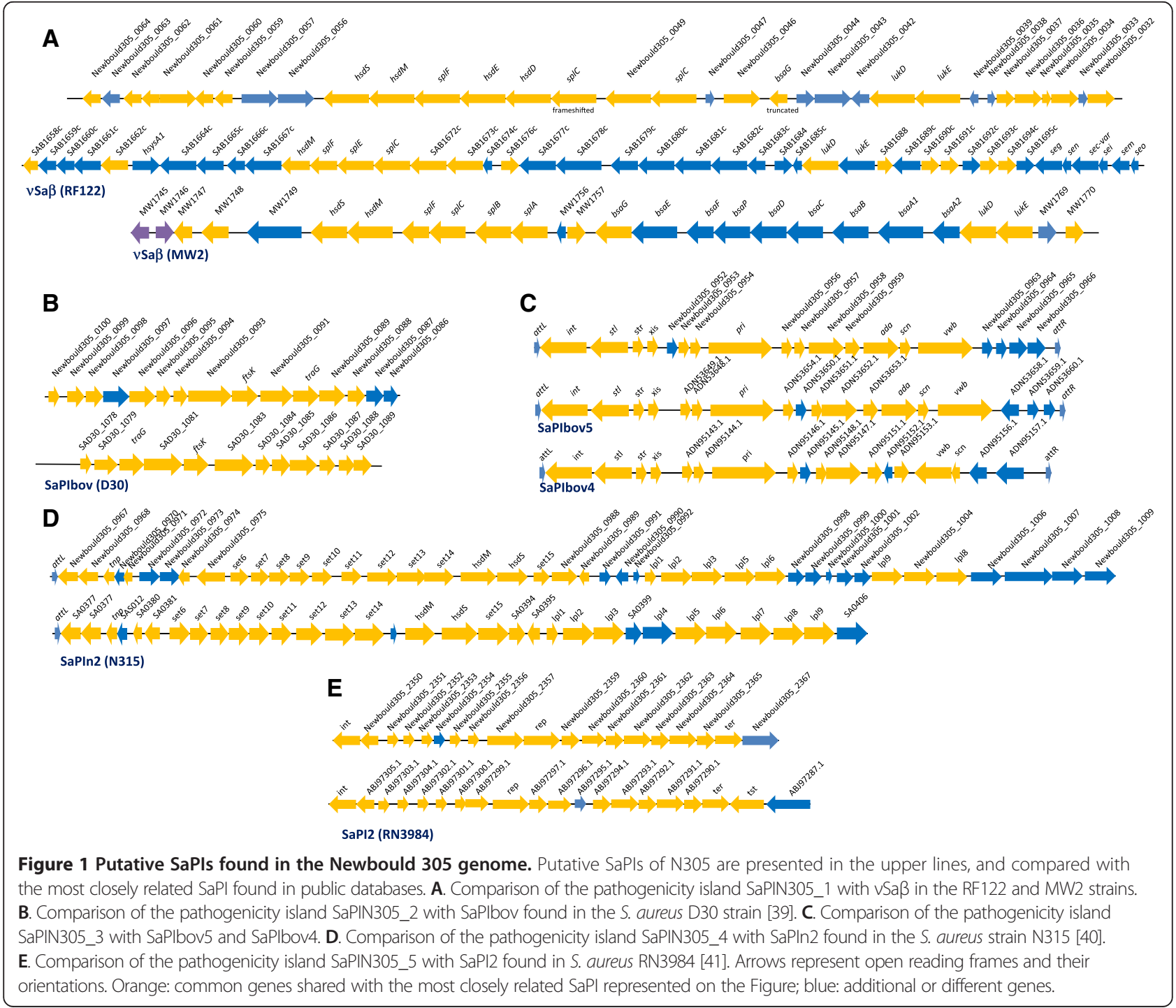


Table 2 Presence (+) or absence (-) of virulence-associated genes in RF122 and Newbould 305

\begin{tabular}{|c|c|c|c|}
\hline \multicolumn{4}{|l|}{ Gene name } \\
\hline Biofilm formation & Function & NB305 & RF122 \\
\hline ica operon & Biofilm synthesis ica operon & + & + \\
\hline bap & Biofilm associated protein & - & - \\
\hline aap & Accumulation-associated protein (associated to biofilm formation) & $+^{*}$ & - \\
\hline ypfP, ItaA, ItaS, tag and dlt operons & Teichoic and Lipoteichoic acid synthesis & + & + \\
\hline cap operon & Capsular polysaccharide biosynthesis & + & + \\
\hline Secreted toxins & Function & NB305 & RF122 \\
\hline lukE & Leukocidin LukE precursor & + & + \\
\hline lukD & Leukocidin LukD precursor & + & + \\
\hline lukM & Leukocidin chain lukM precursor & - & + \\
\hline lukF'-PV & Panton-Valentine leukocidin LukF'-PV chain & - & + \\
\hline lukF & Leukocidin F subunit & + & + \\
\hline luks & leukocidin/hemolysin toxin subunit S & + & + \\
\hline hla & Alpha-hemolysin precursor & + & + \\
\hline$h / b$ & Beta-hemolysin precursor & + & + \\
\hline hlg (subunits $A, B, C$ ) & Gamma-hemolysin component & + & + \\
\hline hld & Delta-hemolysin & + & - \\
\hline atl & Bifunctional autolysin precursor & + & + \\
\hline tst & Toxic shock syndrome toxin 1 & - & + \\
\hline eta & Exfoliative A & + & + \\
\hline etb & Exfoliative B & - & + \\
\hline sea & Staphylococcal enterotoxin A & + & + \\
\hline sec bov & Bovine variant of Staphylococcal enterotoxin C & - & + \\
\hline seg & Staphylococcal enterotoxin $\mathrm{G}$ & - & + \\
\hline sei & Staphylococcal enterotoxin I & - & + \\
\hline sel & Staphylococcal enterotoxin $L$ & - & + \\
\hline sen & Staphylococcal enterotoxin N & - & + \\
\hline seo & Staphylococcal enterotoxin $\mathrm{O}$ & - & + \\
\hline Colonisation factors & Function & NB305 & RF122 \\
\hline$v w b$ & Secreted von Willebrand factor-binding protein (Wbp) precursor & + & + \\
\hline$v w b^{S b o 5}$ & SaPl-encoded variant of Wbp carried by SaPIbov5 & + & - \\
\hline CIfA & Clumping factor $\mathrm{A}$ & + & + \\
\hline$C l f B$ & Clumping factor $\mathrm{B}$ & + & + \\
\hline$f \cap b A$ & Fibronectin binding protein $\mathrm{A}$ & + & + \\
\hline$f n b B$ & Fibronectin binding protein $\mathrm{B}$ & + & - \\
\hline stl & Transcriptional Repressor SaPI & + & + \\
\hline eap & Extracellular adherence protein & + & + \\
\hline sasG & S. aureus surface protein $\mathrm{G}$ & + & - \\
\hline plsC & 1-acyl-sn-glycerol-3-phosphate acyltransferase & + & - \\
\hline sak & Staphylokinase & - & - \\
\hline spa & Immunoglobulin $\mathrm{G}$ binding protein A precursor & + & + \\
\hline
\end{tabular}

"Newbould 305_2513 possess a CWA domain and is 67\% similar to aap gene of S. epidermidis (GeneBank accession number YP_189945). 
exfoliative toxin B (Etb) and the enterotoxins Cbov/G/I/ L/N/O (SECbov, SEG, SEI, SEL, SEN, SEO). All these proteins are secreted toxins.

Particular focus on microbial surface components recognizing adhesive matrix molecule (MSCRAMMs) genes revealed that their number was higher in N305 than in RF122. Although both strains carry the gene coding for fibronectin-binding protein $\mathrm{A}(f n b A)$, we found that the fnbA sequence in N305 had two additional fibronectinbinding domains when compared to that of RF122 (Figure 2).

\section{The same biofilm formation but broader coagulase activity spectrum and higher cytotoxic capacities for N305 during in vitro assays}

Based on the differences in gene content revealed by sequence analysis, phenotypic differences could be expected in terms of biofilm formation, coagulase activity, cytotoxicity and invasive capacities. These four properties were tested in vitro at the phenotype level (see Materials and methods for details). In line with the absence of differences in terms of the content of genes involved in biofilm formation, the two strains did not display any significant differences in phenotype. Indeed, RF122 and N305 revealed the same ability to form a biofilm on an abiotic surface, as determined by Crystal violet staining on a plastic surface (data not shown). By contrast, with respect to coagulase activity, the presence of $v w b^{\text {Sbo5 }}$ (Newbould 305_0962) in the N305 genome (Figure 1C), whose product was also found in the N305 surface exposed protein (Additional file 2), was clearly associated with an increased range of coagulase activity. N305 indeed clotted rabbit, goat and bovine plasma, whereas RF122 only clotted rabbit plasma (Figure 3A). Furthermore, N305 displayed greater cytotoxicity on MAC-T cells than RF122 after co-incubation with their respective supernatants. The viability of cells incubated with the N305 supernatant was 89\% lower than under control conditions, whereas the viability of cells incubated with the RF122 supernatant was 36\% lower (Figure 3B).
N305 supernatant also presented a higher ability to hydrolyse caseins as shown by the translucent halo around the well of N305 deposit (Additional file 3).

\section{Comprehensive analysis of the proteome of S. aureus Newbould 305}

A comprehensive analysis of the $\mathrm{N} 305$ proteome (total cell, surface and secreted proteins) was carried out on cultures grown under conditions mimicking the context of mastitis, as described previously [32]. The N305 proteome was compared with that of RF122. A total of 215 proteins were categorized as being differentially produced in N305 or RF122, and were further identified. Sixty-eight proteins (31.6\%) were identified as being overexpressed by RF122, and 147 (68.4\%) by N305. In more detail, a total of 33 proteins (15.4\% of total proteins) were identified in the culture supernatant (Additional file 4), 11 proteins being more abundant in RF122 and 22 in N305. Supernatant gels (Figure 4A and B) displayed the most flagrant proteomic differences between N305 and RF122. In the total cell lysate, 36 proteins (16.7\% of total proteins) were identified (Additional file 5), ten proteins being more abundant in RF122 and 26 in N305. Trypsin shaving enabled the identification of up to 409 proteins because of the sensitivity of this method, and included 146 proteins that were relatively more abundant in one strain $(67.9 \%$ of total proteins) (Additional file 2), with 47 proteins more abundant in RF122 and 99 in N305.

The proteins were classified into COGs as a function of their annotation. Most of the secreted and PSE proteins identified here belonged to cellular processes and signalling categories or were poorly-characterized proteins. Among these, a number of exoproteases were found to be common to both strains (Additional files 4 and 2), while some exoproteases such as Spl proteases (SaPI-N305_1), were also specifically found in N305. Virulence factors (classified in the category of poorlycharacterized proteins) were also found to be specific to N305. These included haemolysins and leukotoxins (alphaand gamma-haemolysins, LukS/F) and proteins involved in

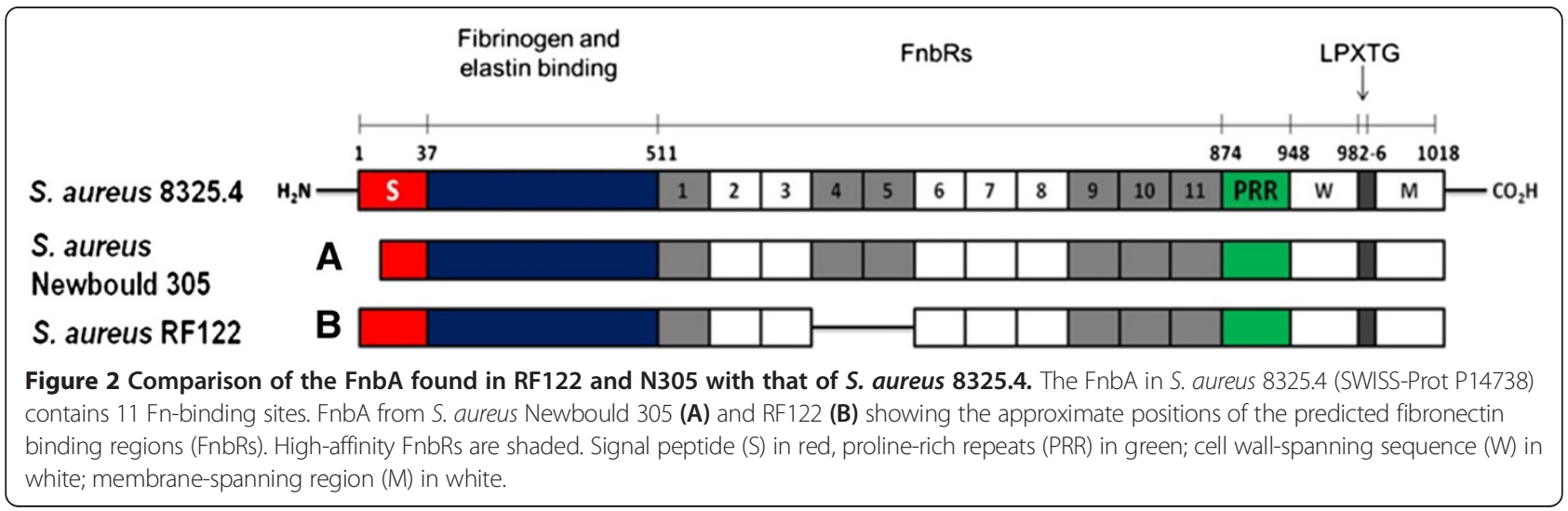



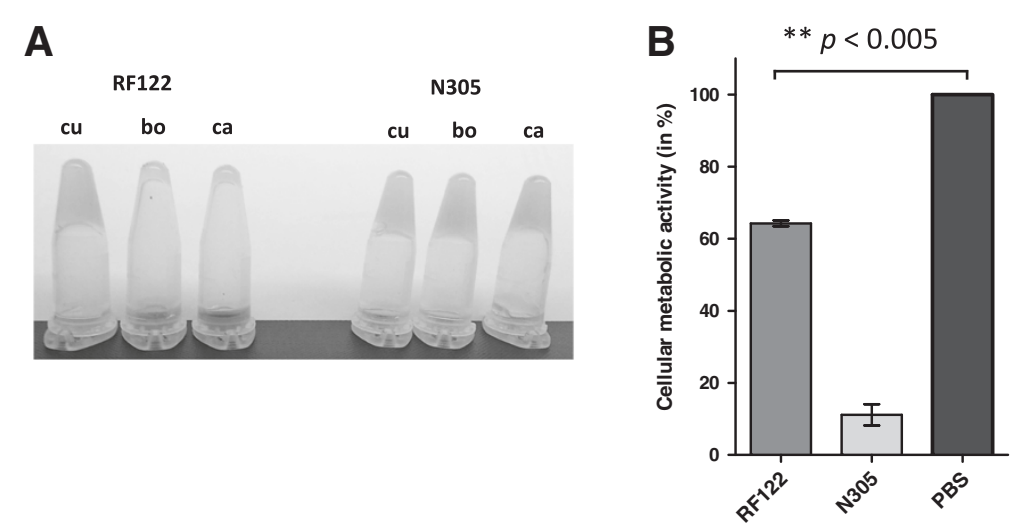

Figure 3 Phenotypic characterization of S. aureus N305 and comparison with RF122. A. Coagulase activity of RF122 and N305. A $10^{8}$ CFU aliquot was prepared from an overnight culture of each strain, washed and re-suspended in rabbit (cu), bovine (bo) or goat (ca) plasma. After a 4-h incubation at $37^{\circ} \mathrm{C}$, the level of coagulation of observed by tilting the tubes. B. Cytotoxic effects of S. aureus RF122 and N305 supernatants on MAC-T cells. S. aureus strains were grown for $24 \mathrm{~h}$ in RPMI with $50 \mathrm{mM}$ deferoxamine. Supernatants (or PBS for the control condition) were mixed in DMEM at a ratio of 1:1 and incubated with MAC-T cells. Cytotoxicity was assessed using the MTT test and relative viability was expressed with regard to PBS-treated cells. Each experiment was performed in triplicate, and differences between the groups were compared using Student's $t$ test. ${ }^{* *} P<0.005$.

adhesion to host tissues (e.g. Newbould305_1324, encoding an extracellular matrix and plasma binding protein) and in evasion of the host immune response (e.g. Spa, vWbp ${ }^{\text {Sbo5 }}$ ). By contrast, RF122 was found to produce leukotoxins (e.g. LukM/F' and LukE) and enterotoxins (e.g. bovine variant of the staphylococcal enterotoxin C sec-bov) as well as iron metabolism proteins (e.g. IsdB and D). As expected, total proteins (as well as the surface exposed proteins identified by trypsin shaving) comprised many more proteins that those grouped in the Metabolism categories.

\section{Discussion}

The outcomes of $S$. aureus mastitis can vary markedly, and are mostly linked to strain-dependent features [3]. By contrast with mastitis induced by other pathogens, one of the most problematic traits of $S$. aureus mastitis is its low cure rate and its propensity to chronicity. Here, we have finely characterized N305 [15], an S. aureus strain that reproducibly induces mild and chronic mastitis in an experimental cow model, and compared it to RF122, a well-documented and highly virulent $S$. aureus strain [25] (J. Ross Fitzgerald, personal communication) which is representative of a common clone which frequently causes bovine mastitis $[9,15]$. These two strains belong to distinct clonal complexes (CC97/ST115 for N305, and CC133/ST151 for RF122), with both strains clustering in groups that include several other bovine strains and strains of human or non-specified origin. Although RF122 has been described as an archetypal bovine strain, it is closely related to human strains. By contrast, N305 is strongly associated with a bovine host $[42,43]$.

Despite their phylogenetic divergence, a comparison of their genome sequences revealed some strong similarities, with a core genome (set of genes common to N305 and RF122) comprising more than $91 \%$ of their gene content (Table 1). However, certain genomic differences were found in their pseudogene contents. The RF122 genome reportedly contains 70 pseudogenes [9], whereas only six pseudogenes are predicted in the N305 genome. Significant differences were also found regarding the genes encoding toxins and surface proteins involved in host invasion. These latter genomic features were confirmed by phenotypic and proteomic characterizations.

In terms of gene regulation, we found that N305 is agrI, while RF122 is agrII. The agr system plays a central role in $S$. aureus virulence expression. Interestingly, agrI bovine strains were recently shown associated to persistence, with high intracellular survival and probably a better adaptation to an intracellular niche, whereas agrII was associated with a low intracellular survival and a probable extracellular niche [44].

\section{An inventory of potential mastitis-associated functions in N305 reflects host adaptation and propensity to chronicity}

A comparison between the N305 and RF122 genomes revealed differences regarding the genes encoding PSE and secreted proteins. The complete $s p l$ operon ( $s p l A, B$, $C, D, E, F$; although $s p l C$ is pseudogenized) was found in $\mathrm{N} 305$ whereas only $s p l B, s p l C$, $s p l E$, and $s p l F$ were found in the RF122 genome sequence. In addition, a series of four serine proteases, including SplB (Newbould 305_0049), SplE, D, and F, encoded by the $s p l$ operon, was found to be relatively more abundant in the N305 supernatant (Table 3). In agreement, we observed a higher ability of N305 to degrade caseins, which is associated to SplA, SplB and SplC in $S$. aureus $[45,46]$. Other differences were found in toxin 


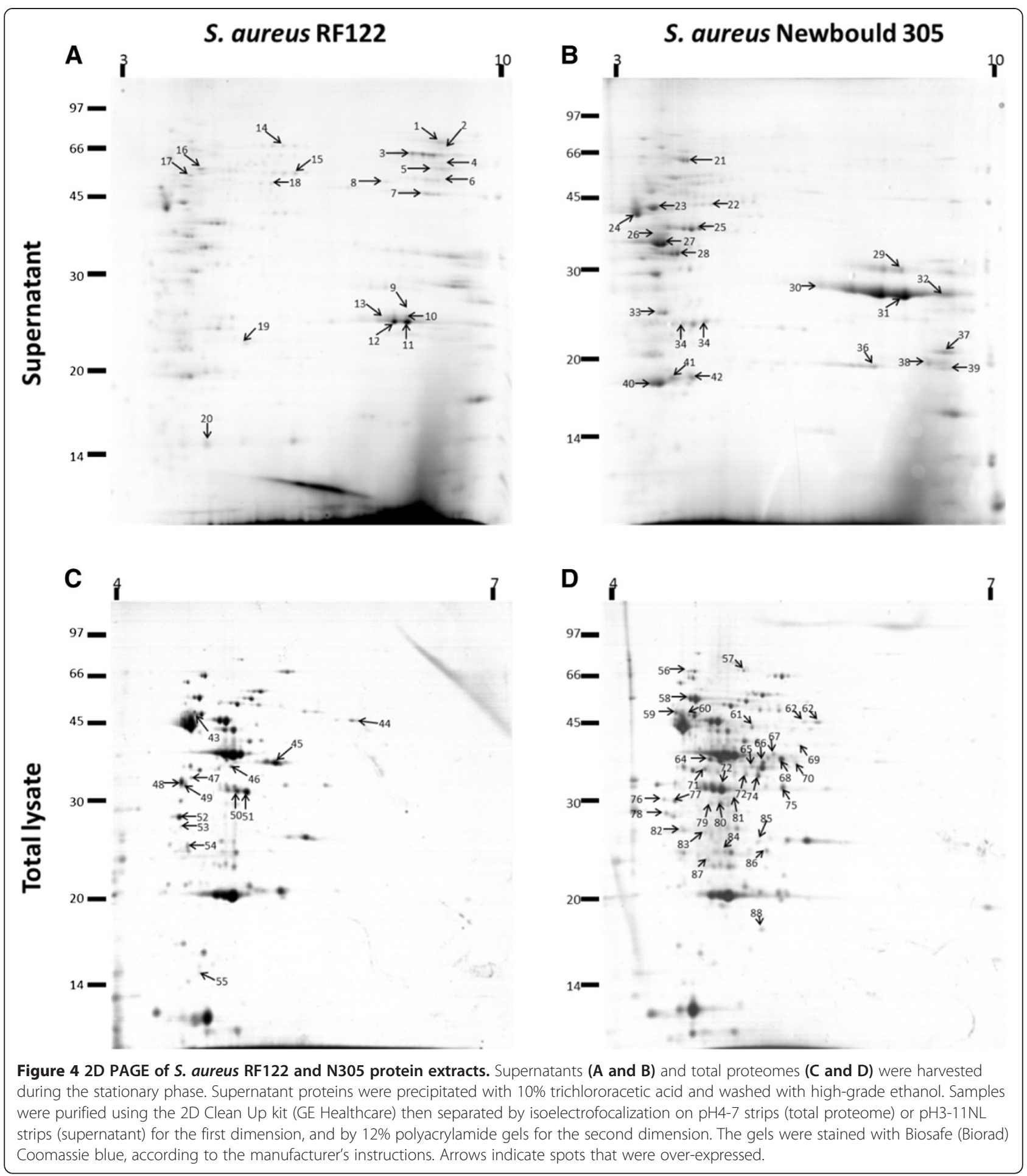

gene contents, which correlated with differences in the composition of MGEs. RF122, which is associated with severe mastitis, was found to be well-equipped with genes encoding enterotoxins, haemolysins, exfoliatin, toxic shock syndrome toxin, and leukocidin, whereas the N305 genome carried fewer and different toxin genes. S. aureus RF122 carried numerous enterotoxin genes, including the bovine-associated variant of staphylococcal enterotoxin $\mathrm{C}$ which is involved in disturbances affecting the immune response and is carried by SaPIbov1 [9]. Unlike N305, RF122 was found to possess $l u k M$ and $l u k F^{\prime}-\mathrm{PV}$ (hereinafter referred to as $\left.l u k F^{\prime}\right)$, a $l u k F-P V$ variant carried by the prophage $\phi$ PV83-pro [47]. These genes form LukM/F' which is involved in cytotoxicity against polynuclear neutrophils, 
Table 3 Compilation of potentially virulence associated proteins identified in this work

\begin{tabular}{|c|c|c|c|c|c|c|c|c|}
\hline \multirow[b]{2}{*}{ Name of the protein ${ }^{a}$} & \multirow[b]{2}{*}{ Locus name ${ }^{\mathbf{b}}$} & \multicolumn{2}{|l|}{ Access. $^{c}$} & \multirow[b]{2}{*}{ Mass $^{\mathrm{d}}$} & \multirow[b]{2}{*}{ Loc. ${ }^{e}$} & \multicolumn{3}{|c|}{ Method $^{f}$} \\
\hline & & RF122 & N305 & & & Exo. & Tot. & Shav. \\
\hline \multicolumn{9}{|l|}{ CELLULAR PROCESSES AND SIGNALING } \\
\hline \multicolumn{9}{|l|}{$\begin{array}{l}\text { Cell cycle control, cell division, } \\
\text { chromosome partitioning }\end{array}$} \\
\hline Probable transglycosylase IsaA & is $a A$ & Q2YWD9 & JOL078 & 28.2 & $\mathrm{~S}$ & RF122 & & RF122, N305 \\
\hline \multicolumn{9}{|l|}{ Cell wall/membrane/envelope biogenesis } \\
\hline Iron-regulated surface determinant protein A & is $d A$ & Q2YX95 & JOKNZ4 & & W & & & RF122, N305 \\
\hline Iron-regulated surface determinant protein B & $i s d B$ & Q2YX96 & J1ET39 & 72.0 & W & RF122 & & RF122, N305 \\
\hline Iron-regulated surface determinant protein $C$ & isdC & Q2YX94 & JOKVY4 & & & & & RF122, N305 \\
\hline Iron-regulated protein & $i s d D$ & Q2YX93 & JOUGM1 & 41.2 & U & & & RF122 \\
\hline Lipoteichoic acid synthase & Itas & Q2YSL2 & J1EW90 & 74.2 & $\mathrm{C} / \mathrm{M}$ & RF122 & & \\
\hline Penicillin-binding protein 2 & pbp2 & Q2YY56 & J1EUU3 & 80.2 & $\mathrm{C} / \mathrm{M}$ & & & RF122 \\
\hline \multicolumn{9}{|l|}{$\begin{array}{l}\text { Post-translational modification, protein } \\
\text { turnover, and chaperones }\end{array}$} \\
\hline Serine protease SplE & splE & Q2YTM5 & J1EZ78 & 25.6 & $\mathrm{C} / \mathrm{M}$ & N305 & & \\
\hline Serine protease SplF & splF & Q2YTM6 & JoKV93 & 25.6 & $S$ & N305 & & \\
\hline Serine protease SplD & $s p / D$ & & JOL226 & 25.6 & $\mathrm{~S}$ & N305 & & \\
\hline Serine proteinase (Sp|B) & Newbould 305_0049 & Q2YTM3 & JoUNB6 & 27.8 & S & N305 & & \\
\hline Chaperone protein DnaK & dnak & Q2YT47 & J1EZS6 & 66.2 & C & & RF122 & RF122, N305 \\
\hline Alkyl hydroperoxide reductase subunit F & $a h p F$ & Q2YVH8 & JOKUQ5 & 54.5 & $\mathrm{C} / \mathrm{M}$ & & RF122 & RF122, N305 \\
\hline Alkyl hydroperoxide reductase subunit $C$ & $a h p C$ & Q2YVK2 & J1EYK8 & 20.9 & C & & RF122 & RF122, N305 \\
\hline Trigger factor & tig & Q2YTB4 & JOKVL9 & 48.4 & C & & N305 & RF122, N305 \\
\hline \multicolumn{9}{|l|}{ Defense mechanisms } \\
\hline Alkaline shock protein 23 & asp23 & Q2YYG3 & JOKY19 & 18.6 & U & & N305 & RF122, N305 \\
\hline \multicolumn{9}{|l|}{ INFORMATION STORAGE AND PROCESSING } \\
\hline \multicolumn{9}{|l|}{ Replication, recombination and repair } \\
\hline Thermonuclease & nucl & Q2YXU2 & JOUHM2 & 21.8 & $\mathrm{~S}$ & & & RF122, N305 \\
\hline \multicolumn{9}{|c|}{ Translation, ribosomal structure and biogenesis } \\
\hline Elongation factor Ts & tsf & Q2YXL1 & JOKWZ6 & 32.3 & C & N305 & RF122 & N305 \\
\hline Elongation factor Tu & tuf & Q2YSB3 & J1EVM7 & 43.0 & C & & N305 & RF122, N305 \\
\hline \multicolumn{9}{|l|}{ METABOLISM } \\
\hline \multicolumn{9}{|l|}{ Carbohydrate transport and metabolism } \\
\hline Glyceraldehyde-3-phosphate dehydrogenase & gap & Q2YSF2 & JOKSH5 & 36.2 & C & N305 & & RF122, N305 \\
\hline Glucose-6-phosphate isomerase & pgi & Q2YWS3 & J0UKP5 & 49.7 & C & N305 & & \\
\hline Enolase & eno & Q2YSE8 & J1EWJ2 & 47.0 & C & N305 & & RF122, N305 \\
\hline Phosphoglycerate kinase & pgk & Q2YSF1 & J1EWC9 & 42.5 & C & N305 & N305 & RF122, N305 \\
\hline \multicolumn{9}{|l|}{ Inorganic ion transport and metabolism } \\
\hline Superoxide dismutase M & sodM & Q2YUU9 & J0UM22 & 22.9 & $\mathrm{~S}$ & N305 & & \\
\hline \multicolumn{9}{|l|}{ POORLY CHARACTERIZED } \\
\hline Gamma-hemolysin component A & $h \lg A$ & Q2YVZ2 & JOKNX1 & 36.3 & $S$ & & & N305 \\
\hline Gamma-hemolysin component B & $h \lg B$ & Q2YVZ0 & JOKWW4 & 36.6 & $S$ & & & RF122, N305 \\
\hline Gamma-hemolysin component C & $h \lg C$ & Q2YVZ1 & J1ET20 & 35.5 & $\mathrm{~S}$ & N305 & & \\
\hline Staphylococcal enterotoxin C-bovine & sec-bov & Q2YVN9 & & 31.2 & S & RF122 & & \\
\hline Superantigen-like protein 7 & set5 & Q2YVR9 & J1EYV6 & 26.0 & $\mathrm{~S}$ & N305 & & \\
\hline
\end{tabular}


Table 3 Compilation of potentially virulence associated proteins identified in this work (Continued)

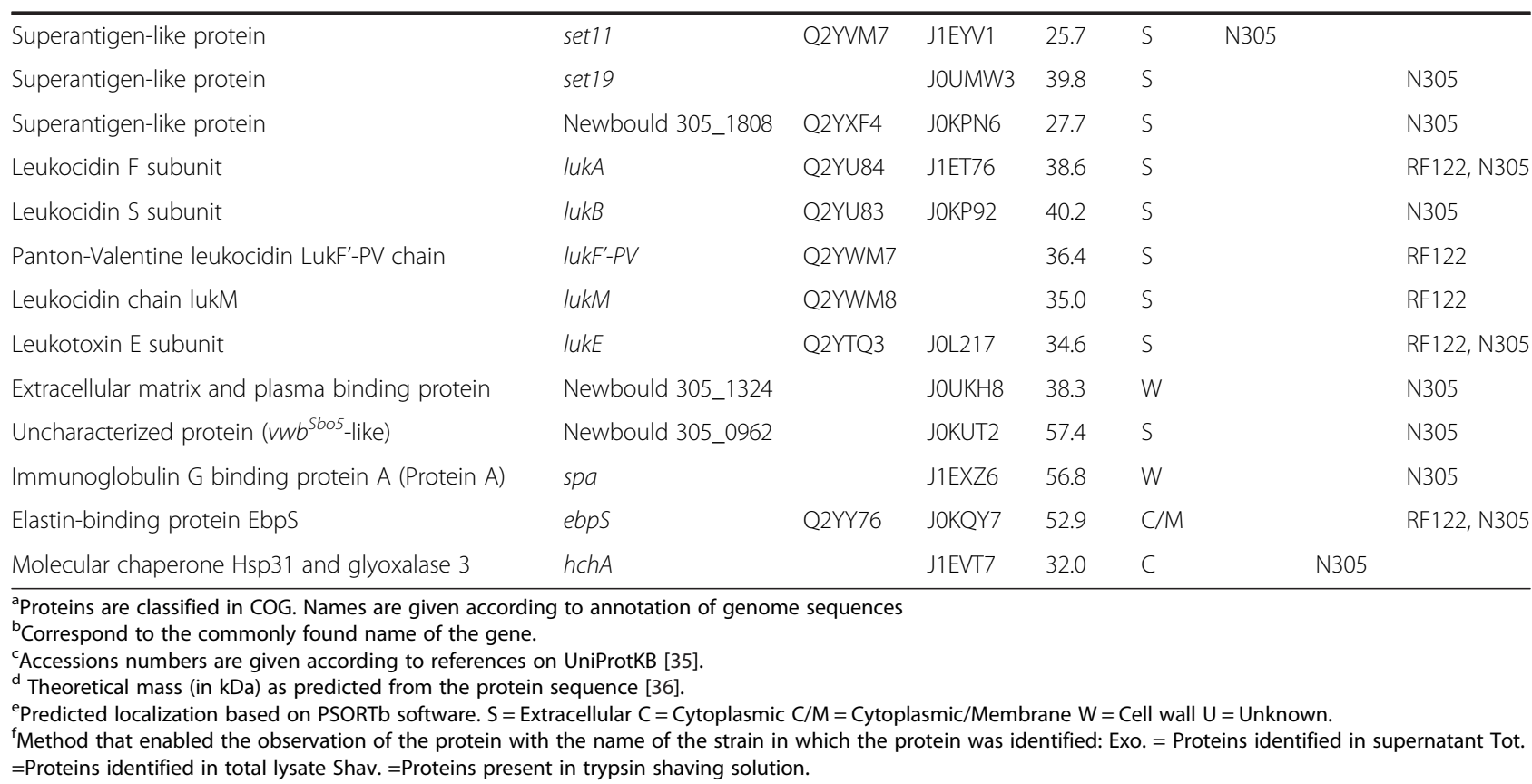

mainly described during a strong inflammatory reaction in the mammary gland. LukM/F' is more efficient against bovine leukocytes than any other staphylococcal toxin, including Panton-Valentine leukocidin [5,48,49]. As for other leukocidins, both strains contained the $l u k \mathrm{D} / \mathrm{E}$ genes and $l u k \mathrm{~F} / \mathrm{S}$ genes, also described as $l u k \mathrm{~B} / \mathrm{A}$ or $l u k \mathrm{G} / \mathrm{H}$, respectively [50,51], and LukS and LukF subunits were only found in N305 protein samples (Table 3). However, the LukM/F' leukotoxin, found in RF122, has a higher affinity for bovine myeloid lineage cells $[5,52]$ and has been shown to be associated with severe clinical mastitis and to be highly prevalent in gangrenous mastitis isolates [7,53]. Other toxin genes are absent from the N305 genome when compared to that of RF122, which might explain its less virulent phenotype during mastitis. Genes encoding for toxic shock syndrome toxin, exfoliatin B and enterotoxins, such as sec which is carried by SaPIbov, and seg, sei, sen, seo, carried by an enterotoxin gene cluster $(e g c)$, were indeed present in RF122 and absent from the N305 genome. Enterotoxins play a major role during staphylococcal infections and can induce a strong immune response in the mammary gland [54]. Analysis of the secretomes of RF122 and N305 confirmed some of the differences observed in the gene content, but it also revealed differences in the production of virulence factors whose genes were present in both genomes. Hence the production of haemolysins ( $\alpha$ - and $\gamma$ haemolysin) was more pronounced in N305, despite the presence of haemolysin-encoding genes in both strains. In line with this, N305 displayed a stronger cytotoxic potential than RF122, as shown by an in vitro MTT assay of MAC-T cells. However, RF122 has been described as a strain that produces high levels of $\alpha$-haemolysin [55]. This discrepancy between the genomic and proteomic profiles and the expected cytotoxicity phenotype underlines the importance of the in vivo validation of in silico and proteomic analyses. The virulence of $S$. aureus is obviously associated with its gene content, but also with its capacity to express this genetic equipment in a specific context. The differences observed here therefore advocated for more severe mastitis with RF122.

Interestingly, SaPI-N305_3, one of the SaPIs predicted in silico by PIPS analysis, was absent from the RF122 genome and shared homology with the previously described SaPIbov4 and SaPIbov5 [56]. This putative SaPI carries the Newbould 305_0962 gene whose product was found to be surface-exposed by trypsin shaving in N305. This gene shares homology with SaPIbov4_ORF15, a gene encoding a bovine and SaPI-associated variant of von Willebrand factor binding protein which has been described in the Staphylococcus aureus strain BA4 pathogenicity island SaPIbov4 [57]. These bovine variants of vWbp (identified in SaPIbov4 and SaPIbov5) have been shown to provide carrier $S$. aureus strains with an ability to specifically coagulate ruminant plasma, whereas strains that do not carry these SaPIs (such as RF122) coagulate rabbit but not ruminant plasma [56]. We were able to show that N305 did indeed clot ruminant (bovine and caprine) plasma. This capacity to coagulate plasma is correlated with an ability to induce abscesses during infections [58]. The formation of abscesses is a mechanism of bacterial resistance against host immune cells. N305 is therefore endowed with ruminant- 
specific coagulation capacities which reflect its adaptation to the bovine host and correlate with its propensity to induce chronic mastitis.

\section{S. aureus N305 is suitably armed to invade host cells}

A genomic comparison of $S$. aureus N305 and RF122 also revealed differences in colonization and invasion factors. Most of these factors belong to surface proteins such as Secretable Expanded Repertoire Adhesive Molecules (SERAMs) or MSCRAMMs, which participate in both adhesion and the internalization of $S$. aureus in host cells [59]. SERAMs or MSCRAMMs interact with host proteins such as fibronectin, collagen and elastin, and trigger invasion. Numerous studies have reported the importance of these factors during an infection. In particular, fibronectin-binding proteins are considered to be the principal staphylococcal proteins involved in $S$. aureus internalization in host cells [60]. The analysis of the N305 genome using the SurfG + package [27] enabled the identification of PSE proteins. When the genome comparison of RF122 and N305 was focused on these PSE proteins, it revealed that N305 is better equipped than RF122 to achieve host invasion. S. aureus N305 indeed possesses two fibronectin-binding proteins $(f n b A$ and $f n b B)$ rather than one for RF122 ( $f n b A)$. Furthermore, a comparison of the predicted FnbA protein sequence revealed that N305 FnbA presented two additional fibronectin-binding domains, and RF122 FnbA only one. This suggests a greater affinity of N305 for fibronectin. It should be noted that fibronectin-binding proteins have been shown to be indispensable to the internalization of $S$. aureus into host cells [60,61]. Other surface protein genes were found in N305 while they were missing from the RF122 genome.

Biofilm formation was not significantly different in the two strains, in the conditions used (on abiotic surface). Although bap gene is reportedly associated with chronic mastitis isolates [8], its absence does not hinder N305 to induce chronic mastitis. Moreover, the sasG and pls genes, known to participate in host colonization and modulate pathogen internalization, were also found in N305 only. These observations correlate well with previous studies by our laboratory which compared the adhesion and internalization capacities of both strains, in vitro, on bovine MEC cultures (MAC-T line). The adhesion and internalization rates of N305 were indeed significantly higher than those of RF122 [24]. These capacities seem to favour host invasion by $S$. aureus N305, and together with the smaller number of toxin genes and host-adaptation features such as production of the bovine variant of $\mathrm{vWbp}$, may account for a milder but chronic phenotype in N305 mastitis.

Some moonlighting proteins were also found in the proteomic profiles. Proteins identified as being relatively more abundant in the N305 secretome formed part of the "Carbohydrate transport and metabolism" COG category and were also involved in adhesion and colonization of host tissue, as has been reported for enolase $[62,63]$, glyceraldehyde-3-phosphate deshydrogenase (GAPDH) [64] and phosphoglycerate kinase (pgk) [65]. Other cytoplasmic proteins reportedly involved in adhesion, such as glucose-6-phosphate isomerase (pgi) [66], fructose-biphosphate aldolase $(f d a)$ [67], superoxide dismutase $(s o d)$ [68] and elongation factor $\mathrm{Tu}(t u f)$ [69], were also found, but in the N305 supernatant only (Figure 4). The fact that N305 expresses more of these proteins than RF122 may also account for N305's better capacities to adhere, internalize and cause chronic infections.

\section{Conclusions}

N305 harbours fewer toxin genes but more colonization and invasion factors than RF122. In vitro, coagulation, proteolysis and cytotoxicity were significantly higher in N305 compared to RF122 as well as adhesion and internalisation, as previously demonstrated in Bouchard et al. [24]. This correlated well with its gene content and proteomic profile. The range of bovine-adaptive features might account for the propensity of N305 to persistence and mild and chronic mastitis, which is more difficult to detect and cure. By contrast, RF122 appeared to be less well equipped in terms of its genes related to hostadaptation and tissue invasion, but better equipped in toxin genes, and therefore more prone to inducing a severe inflammatory response. Whether these two profiles correspond to the evolutionary strategies of $S$. aureus bovine strains towards a commensal or strictly pathogenic lifestyle is not yet known, and this point deserves further investigation, including epidemiological studies. In line with this, based on MLST data, Smith et al. suggested that N305 should be considered as a teat skin associated strains [70]. S. aureus N305 nevertheless represents a strain of choice for further study to improve our understanding of the pathogenesis of $S$. aureus in the context of chronic mastitis. A complete demonstration of the involvement of the determinants identified here would require further experiments such as gene disruption and virulence determination in vivo. The genome sequence and fine characterization of this strain is a first necessary step towards developing strategies to understand, prevent and combat this disease.

\section{Additional files}

Additional file 1: CDS classifications of $S$. aureus Newbould 305 and RF122 in the biological process. The assignment of protein functions to the ORFs of the N305 (A) and RF122 (B) genomes was performed manually using the results from BLASTP and the COG (Clusters of Orthologous Groups). 
The percentage of genes encoding transposases and their inactivated derivatives (COG L) was $5.5 \%$ of the total genes with COGs classifications in Newbould 305.

Additional file 2: Proteins identified with the trypsin shaving method. This table presents the proteins identified by mass spectrometry after a trypsin treatment of bacterial surface (see Materials and methods for details) for RF122 and N305 strains.

Additional file 3: Proteolytic activity of Newbould 305 and RF122 supernatants assessed on PCA agar medium supplemented with $5 \%$ skimmed milk. Proteolysis assays on PCA gelose added with $5 \%$ of skimmed milk. Culture supernatants of S. aureus RF122 (A) and Newbould 305 (B) were concentrated 10x and filtered before depositing $50 \mu \mathrm{L}$ in a well. A halo of proteolysis can be observed with N305.

Additional file 4: Proteins identified as differentially abundant in secretome of S. aureus RF122 and N305. This table presents the proteins identified by mass spectrometry (see Materials and methods for details) in the culture supernatants of RF122 and N305 strains.

Additional file 5: Proteins identified as differentially expressed in the total lysate by S. aureus RF122 and N305. This table presents the proteins identified by mass spectrometry (see Materials and methods for details) in the whole cell lysates of RF122 and N305 strains.

\section{Competing interests}

The authors declare that they have no competing interests.

\section{Authors' contributions}

$V P, D B, L R, A M, N B$ and SE participated in the phenotype characterizations, $V P, J J$ and GJ carried out the 2-DE analyses, participated in the identification of the proteins by mass spectrometry, SE, JS, PF and YLL participated in the design of the study and in the results analyses, DH, PF and JS carried out the genome sequencing and genome sequence analyses, SA, HF, VA and PF carried out the bioinformatics analyses, SE and YLL conceived the study, and participated in its design and coordination. All authors read and approved the final manuscript.

\section{Authors' information}

Sergine Even and Yves Le Loir share credit in senior co-authorship.

\section{Acknowledgements}

VP was the recipient of a Région Bretagne-INRA PhD fellowship. DB was the recipient of fellowship from the French Ministry of Research and Higher Education. SA was the recipient of a CAPES-COFECUB fellowship (project 720/11). Yves Le Loir is the recipient of a PVE grant (71/2013) from Programa Ciências sem Fronteiras. The authors would like to thank Dr Florence Gilbert and Dr Pascal Rainard (INRA Tours, France) for providing the Newbould 305 strain, Philippe Lamberton and Jean-Marc Aubry (INRA Rennes, France) for supplying cow and goat blood samples, respectively, and Dr Régine Talon and Dr Sabine Leroy (INRA Clermont, France) for allowing us access to the genome sequence of Staphylococcus xylosus C2a.

\section{Author details}

${ }^{1}$ INRA, UMR 1253 STLO, 65 rue de Saint Brieuc, 35042 Rennes Cedex, France. ${ }^{2}$ Agrocampus Ouest, UMR1253 STLO, 85 rue de Saint Brieuc, 35042 Rennes Cedex, France. Instituto de Ciências Biológicas, Universidade Federal de Minas Gerais, Belo Horizonte, MG, Brasil. ${ }^{4}$ Genomic Research Laboratory, Service of Infectious Diseases, University of Geneva Hospitals (HUG), CH-1211 Geneva 14, Switzerland.

Received: 25 June 2014 Accepted: 1 October 2014

Published online: 14 October 2014

\section{References}

1. Le Maréchal C, Seyffert N, Jardin J, Hernandez D, Jan G, Rault L, Azevedo V, François P, Schrenzel J, van de Guchte M, Even S, Berkova N, Thiéry R, Fitzgerald JR, Vautor E, Le Loir Y: Molecular basis of virulence in Staphylococcus aureus mastitis. PLoS One 2011, 6:e27354.

2. Peton V, Le Loir Y: Staphylococcus aureus in veterinary medicine. Infect Genet Evol 2014, 21:602-615.
3. Le Maréchal C, Jardin J, Jan G, Even S, Pulido C, Guibert J-M, Hernandez D, François P, Schrenzel J, Demon D, Meyer E, Berkova N, Thiéry R, Vautor E, Le Loir Y: Staphylococcus aureus seroproteomes discriminate ruminant isolates causing mild or severe mastitis. Vet Res 2011, 42:35.

4. Burvenich C, Van Merris V, Mehrzad J, Diez-Fraile A, Duchateau L: Severity of $E$. coli mastitis is mainly determined by cow factors. Vet Res 2003, 34:521-564.

5. Barrio MB, Rainard P, Prévost G: LukM/LukF'-PV is the most active Staphylococcus aureus leukotoxin on bovine neutrophils. Microbes Infect 2006, 8:2068-2074.

6. Liang $X$, Ji $Y$ : Alpha-toxin interferes with integrin-mediated adhesion and internalization of Staphylococcus aureus by epithelial cells. Cell Microbiol 2006, 8:1656-1668.

7. Rainard P: Staphylococcus aureus leucotoxin LukM/F' is secreted and stimulates neutralising antibody response in the course of intramammary infection. Vet Res 2007, 38:685-696.

8. Cucarella C, Tormo MÁ, Úbeda C, Trotonda MP, Monzón M, Peris C, Amorena B, Lasa Í, Penadés JR: Role of Biofilm-Associated Protein Bap in the pathogenesis of bovine Staphylococcus aureus. Infect Immun 2004, 72:2177-2185.

9. Herron-Olson L, Fitzgerald JR, Musser JM, Kapur V: Molecular correlates of host specialization in Staphylococcus aureus. PLoS One 2007, 2:e1120.

10. Guinane CM, Ben Zakour NL, Tormo-Mas MA, Weinert LA, Lowder BV, Cartwright RA, Smyth DS, Smyth CJ, Lindsay JA, Gould KA, Witney A, Hinds J, Bollback JP, Rambaut A, Penades JR, Fitzgerald JR: Evolutionary genomics of Staphylococcus aureus reveals insights into the origin and molecular basis of ruminant host adaptation. Genome Biol Evol 2010, 2:454-466.

11. Le Maréchal C, Hernandez D, Schrenzel J, Even S, Berkova N, Thiéry R, Vautor E, Fitzgerald JR, François P, Le Loir Y: Genome sequences of two Staphylococcus aureus ovine strains that induce severe (strain 011) and mild (strain O46) mastitis. J Bacteriol 2011, 193:2353-2354.

12. Hernandez D, van der Mee-Marquet N, Kluytmans J, Donnio P-Y, Quentin R, Corvaglia A-R, Francois P: Whole-genome sequences of Staphylococcus aureus ST398 strains of animal origin. Genome Announc 2013, 1:e00689-13.

13. Resch G, François P, Morisset D, Stojanov M, Bonetti EJ, Schrenzel J, Sakwinska O, Moreillon P: Human-to-bovine jump of Staphylococcus aureus CC8 is associated with the loss of a $\beta$-hemolysin converting prophage and the acquisition of a new staphylococcal cassette chromosome. PLoS One 2013, 8:e58187.

14. Bouchard D, Peton V, Almeida S, Le Maréchal C, Miyoshi A, Azevedo V, Berkova N, Rault L, Francois P, Schrenzel J, Even S, Hernandez D, Le Loir Y: Genome sequence of Staphylococcus aureus Newbould 305, a strain associated with mild bovine mastitis. J Bacteriol 2012, 194:6292-6293.

15. Prasad LB, Newbould FH: Inoculation of the bovine teat duct with Staphylococcus Aureus: the relationship of teat duct length, milk yield and milking rate to development of intramammary infection. Can Vet $J$ 1968, 9:107-115.

16. Shkreta L, Talbot BG, Diarra MS, Lacasse P: Immune responses to a DNA/ protein vaccination strategy against Staphylococcus aureus induced mastitis in dairy cows. Vaccine 2004, 23:114-126.

17. Watson D: Mastitis Vaccine. 1986. Patent, International Publication Number: WO/1986/006634.

18. Dahnke KR: Treatment of Mastitis. 1999. Patent, International Publication Number: WO1999/055711.

19. Gill JJ, Sabour PM, Leslie KE, Griffiths MW: Bovine whey proteins inhibit the interaction of Staphylococcus aureus and bacteriophage K. J Appl Microbiol 2006, 101:377-386.

20. Kruze J, Ceballos A, Stryhn H, Mella A, Matamoros R, Contreras PA, Leyan V, Wittwer F: Somatic cell count in milk of selenium-supplemented dairy cows after an intramammary challenge with Staphylococcus aureus. J Vet Med A Physiol Pathol Clin Med 2007, 54:478-483.

21. Schmelcher M, Powell AM, Becker SC, Camp MJ, Donovan DM: Chimeric phage lysins act synergistically with lysostaphin to kill mastitis-causing Staphylococcus aureus in murine mammary glands. Appl Environ Microbiol 2012, 78:2297-2305.

22. Bannerman DD, Paape MJ, Lee J-W, Zhao X, Hope JC, Rainard P: Escherichia coli and Staphylococcus aureus elicit differential innate immune responses following intramammary infection. Clin Diagn Lab Immunol 2004, 11:463-472.

23. Hensen SM, Pavicić MJ, Lohuis JA, de Hoog JA, Poutrel B: Location of Staphylococcus aureus within the experimentally infected bovine udder and the expression of capsular polysaccharide type 5 in situ. J Dairy Sci 2000, 83:1966-1975 
24. Bouchard DS, Rault L, Berkova N, Le Loir Y, Even S: Inhibition of Staphylococcus aureus invasion into bovine mammary epithelial cells by contact with live Lactobacillus casei. Appl Environ Microbiol 2013, 79:877-885.

25. Wilson GJC: Genome scale analysis of the role of superantigens in Staphylococcus aureus disease pathogenesis. PhD Thesis. Edinburgh: The University of Edinburgh; 2011

26. Baron F, Cochet MF, Ablain W, Grosset N, Madec MN, Gonnet F, Jan S, Gautier $M$ : Rapid and cost-effective method for microorganism enumeration based on miniaturization of the conventional plate-counting technique. Lait 2006, 86:251-257.

27. Barinov A, Loux V, Hammani A, Nicolas P, Langella P, Ehrlich D, Maguin E, van de Guchte M: Prediction of surface exposed proteins in Streptococcus pyogenes, with a potential application to other Gram-positive bacteria. Proteomics 2009, 9:61-73.

28. Soares SC, Abreu VAC, Ramos RTJ, Cerdeira L, Silva A, Baumbach J, Trost E, Tauch A, Hirata R, Mattos-Guaraldi AL, Miyoshi A, Azevedo V: PIPS: pathogenicity island prediction software. PLoS One 2012, 7:e30848.

29. Rosenstein R, Nerz C, Biswas L, Resch A, Raddatz G, Schuster SC, Götz F: Genome analysis of the meat starter culture bacterium Staphylococcus carnosus TM300. Appl Environ Microbiol 2009, 75:811-822.

30. Tatusov RL, Galperin MY, Natale DA, Koonin EV: The COG database: a tool for genome-scale analysis of protein functions and evolution. Nucleic Acids Res 2000, 28:33-36.

31. Maudsdotter $L$, Jonsson $H$, Roos $S$, Jonsson A-B: Lactobacilli reduce cell cytotoxicity caused by Streptococcus pyogenes by producing lactic acid that degrades the toxic component lipoteichoic acid. Antimicrob Agents Chemother 2011, 55:1622-1628.

32. Le Maréchal C, Jan G, Even S, McCulloch JA, Azevedo V, Thiéry R, Vautor E, Le Loir Y: Development of serological proteome analysis of mastitis by Staphylococcus aureus in ewes. J Microbiol Methods 2009, 79:131-136.

33. Dumas E, Meunier B, Berdagué J-L, Chambon C, Desvaux M, Hébraud M: Comparative analysis of extracellular and intracellular proteomes of Listeria monocytogenes strains reveals a correlation between protein expression and serovar. Appl Environ Microbiol 2008, 74:7399-7409.

34. Shevchenko A, Sunyaev S, Liska A, Bork P, Shevchenko A: Nanoelectrospray tandem mass spectrometry and sequence similarity searching for identification of proteins from organisms with unknown genomes. Methods Mol Biol 2003, 211:221-234.

35. UniProt [http://www.uniprot.org/]

36. X!Tandem pipeline [http://pappso.inra.fr]

37. Yu NY, Wagner JR, Laird MR, Melli G, Rey S, Lo R, Dao P, Sahinalp SC, Ester M, Foster $\sqcup$, Brinkman FSL: PSORTb 3.0: improved protein subcellular localization prediction with refined localization subcategories and predictive capabilities for all prokaryotes. Bioinformatics 2010, 26:1608-1615.

38. Powell S, Szklarczyk D, Trachana K, Roth A, Kuhn M, Muller J, Arnold R, Rattei T, Letunic I, Doerks T, Jensen LJ, von Mering C, Bork P: eggNOG v3.0: orthologous groups covering 1133 organisms at 41 different taxonomic ranges. Nucleic Acids Res 2012, 40:D284-D289.

39. Sivaraman K, Venkataraman N, Tsai J, Dewell S, Cole AM: Genome sequencing and analysis reveals possible determinants of Staphylococcus aureus nasal carriage. BMC Genomics 2008, 9:433.

40. Kuroda M, Ohta T, Uchiyama I, Baba T, Yuzawa H, Kobayashi I, Cui L, Oguchi A, Aoki K, Nagai Y, Lian J, Ito T, Kanamori M, Matsumaru H, Maruyama A, Murakami H, Hosoyama A, Mizutani-Ui Y, Takahashi NK, Sawano T, Inoue R, Kaito C, Sekimizu K, Hirakawa H, Kuhara S, Goto S, Yabuzaki J, Kanehisa M, Yamashita A, Oshima K, et al: Whole genome sequencing of meticillin-resistant Staphylococcus aureus. Lancet 2001, 357:1225-1240.

41. Subedi A, Ubeda C, Adhikari RP, Penadés JR, Novick RP: Sequence analysis reveals genetic exchanges and intraspecific spread of SaPI2, a pathogenicity island involved in menstrual toxic shock. Microbiology 2007, 153:3235-3245.

42. Ben Zakour NL, Sturdevant DE, Even S, Guinane CM, Barbey C, Alves PD, Cochet M-F, Gautier M, Otto M, Fitzgerald JR, Le Loir Y: Genome-wide analysis of ruminant Staphylococcus aureus reveals diversification of the core genome. J Bacteriol 2008, 190:6302-6317.

43. Kozytska S, Stauß D, Pawlik M-C, Hensen S, Eckart M, Ziebuhr W, Witte W, Ohlsen K: Identification of specific genes in Staphylococcus aureus strains associated with bovine mastitis. Vet Microbiol 2010, 145:360-365.

44. Bardiau M, Detilleux J, Farnir F, Mainil JG, Ote I: Associations between properties linked with persistence in a collection of Staphylococcus aureus isolates from bovine mastitis. Vet Microbiol 2014, 169:74-79.
45. Reed SB, Wesson CA, Liou LE, Trumble WR, Schlievert PM, Bohach GA, Bayles KW: Molecular characterization of a novel Staphylococcus aureus serine protease operon. Infect Immun 2001, 69:1521-1527.

46. Stec-Niemczyk J, Pustelny K, Kisielewska M, Bista M, Boulware KT, Stennicke HR, Thogersen IB, Daugherty PS, Enghild JJ, Baczynski K, Popowicz GM Dubin A, Potempa J, Dubin G: Structural and functional characterization of SpIA, an exclusively specific protease of Staphylococcus aureus. Biochem J 2009, 419:555-564.

47. Zou D, Kaneko J, Narita S, Kamio Y: Prophage, $\varphi$ PV83-pro, carrying PantonValentine leukocidin genes, on the Staphylococcus aureus P83 chromosome: comparative analysis of the genome structures of $\varphi$ PV83-pro, QPVL, $\varphi 11$, and other phages. Biosci Biotechnol Biochem 2000, 64:2631-2643.

48. Rainard P, Corrales J-C, Barrio MB, Cochard T, Poutrel B: Leucotoxic activities of Staphylococcus aureus strains isolated from cows, ewes, and goats with mastitis: importance of LukM/LukF'-PV leukotoxin. Clin Diagn Lab Immunol 2003, 10:272-277

49. Yamada T, Tochimaru N, Nakasuji S, Hata E, Kobayashi H, Equchi M, Kaneko J, Kamio Y, Kaidoh T, Takeuchi S: Leukotoxin family genes in Staphylococcus aureus isolated from domestic animals and prevalence of lukM-lukF-PV genes by bacteriophages in bovine isolates. Vet Microbiol 2005, 110:97-103.

50. Ventura CL, Malachowa N, Hammer CH, Nardone GA, Robinson MA, Kobayashi SD, DeLeo FR: Identification of a novel Staphylococcus aureus two-component leukotoxin using cell surface proteomics. PLoS One 2010, 5:e11634.

51. Yanai M, Rocha MA, Matolek AZ, Chintalacharuvu A, Taira Y, Chintalacharuvu K, Beenhouwer DO: Separately or combined, LukG/LukH is functionally unique compared to other saphylococcal bicomponent leukotoxins. PLoS One 2014, 9:e89308.

52. Fromageau A, Cunha P, Gilbert FB, Rainard P: Purified Staphylococcus aureus leukotoxin LukM/F' does not trigger inflammation in the bovine mammary gland. Microb Pathog 2011, 51:396-401.

53. Rainard $P$ : The complement in milk and defense of the bovine mammary gland against infections. Vet Res 2003, 34:647-670.

54. Haenni M, Galofaro L, Ponsin C, Bes M, Laurent F, Madec J-Y: Staphylococcal bovine mastitis in France: enterotoxins, resistance and the human Geraldine methicillin-resistant Staphylococcus aureus clone. J Antimicrob Chemother 2011, 66:216-218.

55. Guinane CM, Sturdevant DE, Herron-Olson L, Otto M, Smyth DS, Villaruz AE, Kapur V, Hartigan PJ, Smyth CJ, Fitzgerald JR: Pathogenomic analysis of the common bovine Staphylococcus aureus clone (ET3): emergence of a virulent subtype with potential risk to public health. J Infect Dis 2008, 197:205-213.

56. Viana D, Selva L, Callanan JJ, Guerrero I, Ferrian S, Corpa JM: Strains of Staphylococcus aureus and pathology associated with chronic suppurative mastitis in rabbits. Vet $J$ 2011, 190:403-407.

57. Viana D, Blanco J, Tormo-Más MÁ, Selva L, Guinane CM, Baselga R, Corpa JM, Lasa Í, Novick RP, Fitzgerald JR, Penadés JR: Adaptation of Staphylococcus aureus to ruminant and equine hosts involves SaPI-carried variants of von Willebrand factor-binding protein: molecular basis of $S$. aureus host adaptation. Mol Microbiol 2010, 77:1583-1594.

58. Cheng AG, McAdow M, Kim HK, Bae T, Missiakas DM, Schneewind O: Contribution of coagulases towards Staphylococcus aureus disease and protective immunity. PLOS Pathog 2010, 6:e1001036.

59. Heilmann C: Adhesion mechanisms of Staphylococci. In Bacterial Adhesion. Edited by Linke D, Goldman A. Netherlands: Springer; 2011:105-123 [Advances in Experimental Medicine and Biology, vol. 715].

60. Fraunholz M, Sinha B: Intracellular Staphylococcus aureus: live-in and let die. Front Cell Infect Microbiol 2012, 2:43

61. Edwards AM, Potter U, Meenan NAG, Potts JR, Massey RC: Staphylococcus aureus keratinocyte invasion is dependent upon multiple high-affinity fibronectin-binding repeats within FnBPA. PLOS One 2011, 6:e18899.

62. Antikainen J, Kuparinen $V$, Lähteenmäki K, Korhonen TK: Enolases from Gram-positive bacterial pathogens and commensal lactobacilli share functional similarity in virulence-associated traits. FEMS Immunol Med Microbiol 2007, 51:526-534.

63. Carneiro CRW, Postol E, Nomizo R, Reis LFL, Brentani RR: Identification of enolase as a laminin-binding protein on the surface of Staphylococcus aureus. Microbes Infect Inst Pasteur 2004, 6:604-608.

64. Madureira P, Baptista M, Vieira M, Magalhães V, Camelo A, Oliveira L, Ribeiro A, Tavares D, Trieu-Cuot P, Vilanova M, Ferreira P: Streptococcus agalactiae GAPDH is a virulence-associated immunomodulatory protein. $J$ Immunol 2007, 178:1379-1387. 
65. Burnham C-AD, Shokoples SE, Tyrrell GJ: Phosphoglycerate kinase inhibits epithelial cell invasion by group B streptococci. Microb Pathog 2005, 38:189-200

66. Kainulainen V, Loimaranta V, Pekkala A, Edelman S, Antikainen J, Kylväjä R, Laaksonen M, Laakkonen L, Finne J, Korhonen TK: Glutamine synthetase and glucose-6-phosphate isomerase Are adhesive moonlighting proteins of Lactobacillus crispatus released by epithelial cathelicidin LL-37. J Bacteriol 2012, 194:2509-2519.

67. Blau K, Portnoi M, Shagan M, Kaganovich A, Rom S, Kafka D, Caspi VC, Porgador A, Givon-Lavi N, Gershoni JM, Dagan R, Nebenzahl YM: Flamingo cadherin: a putative host receptor for Streptococcus pneumoniae. J Infect Dis 2007, 195:1828-1837.

68. Reddy VM, Suleman FG: Mycobacterium avium-superoxide dismutase binds to epithelial cell aldolase, glyceraldehyde-3-phosphate dehydrogenase and cyclophilin A. Microb Pathog 2004, 36:67-74.

69. Dallo SF, Kannan TR, Blaylock MW, Baseman JB: Elongation factor Tu and E1 $\beta$ subunit of pyruvate dehydrogenase complex act as fibronectin binding proteins in Mycoplasma pneumoniae. Mol Microbiol 2002, 46:1041-1051.

70. Smith EM, Green LE, Medley GF, Bird HE, Fox LK, Schukken YH, Kruze JV, Bradley AJ, Zadoks RN, Dowson CG: Multilocus Sequence Typing of intercontinental bovine Staphylococcus aureus isolates. J Clin Microbiol 2005, 43:4737-4743.

doi:10.1186/s13567-014-0106-7

Cite this article as: Peton et al:: Fine-tuned characterization of

Staphylococcus aureus Newbould 305, a strain associated with mild and chronic mastitis in bovines. Veterinary Research 2014 45:106.

\section{Submit your next manuscript to BioMed Central and take full advantage of:}

- Convenient online submission

- Thorough peer review

- No space constraints or color figure charges

- Immediate publication on acceptance

- Inclusion in PubMed, CAS, Scopus and Google Scholar

- Research which is freely available for redistribution 